\title{
The Magnetic Properties of Three Copper(II) Trichloroacetate Adducts with Caffeine and the Crystal Structure of Dicaffeinetetrakis( $\mu$-trichloroacetato)dicopper(II) Dibenzene Solvate, $\left[\mathrm{Cu}\left(\mathrm{CCl}_{3} \mathrm{COO}\right)_{2}\left(\mathrm{C}_{8} \mathrm{H}_{10} \mathrm{~N}_{4} \mathrm{O}_{2}\right)\right]_{2} \cdot 2 \mathrm{C}_{6} \mathrm{H}_{6}$
}

\author{
Hiroshi Horie, ${ }^{a}$ Steinar Husebye, ${ }^{b, c}$ Michinobu Kato, ${ }^{d}$ Edward A. Meyers, ${ }^{b}$ \\ Yoneichiro Muto, ${ }^{a}$ I. Suzuki, ${ }^{e}$ Tadashi Tokii ${ }^{\mathrm{a}}$ and Ralph A. Zingaro ${ }^{\mathrm{b}}$
}

\begin{abstract}
a Department of Chemistry, Faculty of Science and Engineering, Saga University, Saga 840, Japan, ${ }^{b}$ Department of Chemistry, Texas A\&M University, College Station, TX 77843, USA, 'Department of Chemistry, University of Bergen, 5000 Bergen, Norway, 'Department of Chemistry, Aichi Prefectural University, Mizuhoku, Nagoya 467 and ${ }^{\circ}$ Department of Electrical and Computer Engineering, Nagoya Institute of Technology, Showa-ku, Nagoya 466, Japan
\end{abstract}

\begin{abstract}
Horie, H., Husebye, S., Kato, M., Meyers, E. A., Muto, Y., Suzuki, I., Tokii, T. and Zingaro, R. A., 1986. The Magnetic Properties of Three Copper(II) Trichloroacetate Adducts with Caffeine and the Crystal Structure of Dicaffeinetetrakis( $\mu$-trichloroacetato)dicopper(II) Dibenzene Solvate, $\left[\mathrm{Cu}\left(\mathrm{CCl}_{3} \mathrm{COO}\right)_{2}\right.$ $\left.\left(\mathrm{C}_{8} \mathrm{H}_{10} \mathrm{~N}_{4} \mathrm{O}_{2}\right)\right]_{2} \cdot 2 \mathrm{C}_{6} \mathrm{H}_{6}$. - Acta Chem. Scand. A 40: 579-589.

Three copper(II) trichloroacetate adducts with caffeine have been prepared: $\left[\mathrm{Cu}\left(\mathrm{CCl}_{3} \mathrm{COO}\right)_{2}(\mathrm{caf})\right]_{2} \cdot 2 \mathrm{C}_{6} \mathrm{H}_{6}(1),\left[\mathrm{Cu}\left(\mathrm{CCl}_{3} \mathrm{COO}\right)_{2} \text { (caf) }\right]_{2}$, light green form, (2) and a pale green form, (3). All three adducts display a dimer type of antiferromagnetism. Compounds (2) and (3) are magnetically different and (1) and (2) undergo changes in magnetic properties at ca. $200 \mathrm{~K}$, indicating phase changes. The structure of (1) was solved at room temperature. An attempt to solve the low temperature structure had to be abandoned due to cracking of the crystals upon cooling. The dark green crystals of $(1)$ had the following properties: $M_{\mathrm{r}}=1012.53$, monoclinic, $C 2 / m ; a=20.045(6), b=13.715(3), c=10.794(2) \AA ; \beta=119.01(2)^{\circ}$, $V=2592.1 \AA^{3}, Z=2, D_{\mathrm{x}}=1.253 \mathrm{~g} \mathrm{~cm}^{-3} . \lambda(\mathrm{CuK \alpha})=1.54184 \AA, \mu=72.5 \mathrm{~cm}^{-1}$, $F(000)=1324, T=296 \mathrm{~K}$, final $R=0.068$ for 1888 unique, observed reflections. The complex has the structure usually found in dimeric copper carboxylates of the type $\left[\mathrm{Cu}(\mathrm{RCOO})_{2} \mathrm{~L}\right]_{2}$, each copper atom in the centrosymmetric dimers having distorted square pyramidal symmetry with $\mathrm{N} 9$ of the caffeine molecule in the apical position and relatively long $\mathrm{Cu}-\mathrm{Cu}$ distances of $2.852(1) \AA$. The $\mathrm{Cu}-\mathrm{O}$ bond lengths average $1.973 \AA, \mathrm{Cu}-\mathrm{N} 9=2.121(5) \AA$ and the angle $\mathrm{Cu}--\mathrm{Cu}-\mathrm{N} 9$ is 163.4 (2) ${ }^{\circ}$. A singlet-triplet energy separation, $-2 J$, of only $194.5 \mathrm{~cm}^{-1}$ was found. The EPR spectrum at room temperature of (3) differed from the spectra of (1) and (2), possibly indicating trigonal bipyramidal coordination to $\mathrm{Cu}$ (II). However, after the phase change at low temperature, $(1)$ displays a similar spectrum.
\end{abstract}

The recent structural studies on dimeric copper(II) carboxylate adducts, $\left[\mathrm{Cu}(\mathrm{RCOO})_{2} \mathrm{~L}\right]_{2}$, have demonstrated that the metal-metal distance becomes longer as either the acidity of the parent carboxylic acid, $\mathrm{RCOOH},{ }^{1}$ or the basicity of the axial ligand, $\mathrm{L},{ }^{2}$ becomes greater. A greater $\mathrm{Cu}-\mathrm{Cu}$ distance is usually associated with a langer displacement of the copper(II) ions from the equatorial plane containing four oxygen atoms.
Consequently, the variations of both the group $\mathrm{R}$ and the ligand $\mathrm{L}$ affect the strength of the $\mathrm{Cu}-\mathrm{O}$ bonds in the $\mathrm{CuO}_{4}$ basal plane with an accompanying deformation of the bridging framework. In thirteen dimeric copper(II) acetate adducts, the $\mathrm{Cu}-\mathrm{Cu}$ distances $(2.581-2.671 \AA)^{2}$ span a range of $0.09 \AA$. On the other hand, the $\mathrm{Cu}-\mathrm{Cu}$ distances found for dimeric copper(II) trichloroacetate adducts, $\left[\mathrm{Cu}\left(\mathrm{CCl}_{3} \mathrm{COO}\right)_{2} \mathrm{~L}\right]_{2}$, vary quite con- 
<smiles>O=C1OC(O)(C(=O)O)OC1=O</smiles><smiles>[Li]OCCO</smiles><smiles>[SiH3]</smiles><smiles>[18OH]</smiles>

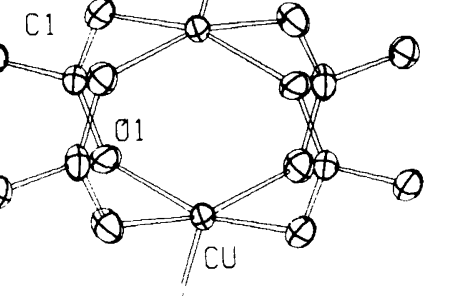<smiles>[GeH3]</smiles>

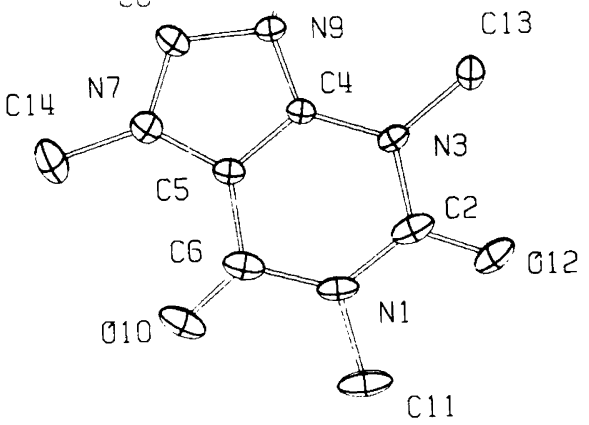

Fig. 1. The structure of the dimer, (1).

siderably: $2.731 \AA$ for $\mathrm{L}=$ benzonitrile,${ }^{3} 2.776 \AA$ for $\mathrm{L}=2$-chloropyridine, ${ }^{1}$ and $3.256 \AA$ for $\mathrm{L}=$ 2,2,6,6,-tetramethylpiperidinyl-1-oxy. ${ }^{4}$ These structural data indicate that the flexibility of the bridging trichloroacetate ligand is quite great.
Table 1. Positional parameters and their estimated standard deviations. ${ }^{a}$

\begin{tabular}{|c|c|c|c|}
\hline Atom & $x$ & $y$ & $z$ \\
\hline $\mathrm{Cu}$ & $0.6923(5)$ & 0 & $0.13171(9)$ \\
\hline $\mathrm{Cl} 1$ & $0.1258(6)$ & $0.2995(5)$ & $-0.0351(9)$ \\
\hline $\mathrm{Cl} 2$ & $0.0281(4)$ & $0.2449(9)$ & $-0.3211(7)$ \\
\hline $\mathrm{Cl} 3$ & $0.1623(4)$ & $0.1429(9)$ & $-0.1588(10)$ \\
\hline 01 & $0.0903(2)$ & $0.1008(3)$ & $0.0229(3)$ \\
\hline $\mathrm{O} 2$ & $-0.0170(2)$ & $0.0998(3)$ & $-0.1831(3)$ \\
\hline C1 & $0.0492(3)$ & $0.1262(4)$ & $-0.0989(5)$ \\
\hline C3 & $0.0859(2)$ & $0.2021(4)$ & $-0.1550(4)$ \\
\hline 010 & $0.4412(3)$ & 0 & $0.6233(7)$ \\
\hline O12 & $0.2650(4)$ & 0 & $0.7745(5)$ \\
\hline N1 & $0.3528(3)$ & 0 & $0.6982(6)$ \\
\hline N3 & $0.2186(3)$ & 0 & $0.5352(5)$ \\
\hline N7 & $0.3106(3)$ & 0 & $0.3270(6)$ \\
\hline N9 & $0.1861(3)$ & 0 & $0.2879(5)$ \\
\hline $\mathrm{C} 2$ & $0.2782(5)$ & 0 & $0.6748(7)$ \\
\hline C4 & $0.2358(4)$ & 0 & $0.4259(6)$ \\
\hline C5 & $0.3099(4)$ & 0 & $0.4523(7)$ \\
\hline C6 & $0.3741(4)$ & 0 & $0.5934(8)$ \\
\hline $\mathrm{C} 8$ & $0.2346(4)$ & 0 & $0.2274(8)$ \\
\hline C11 & $0.4122(6)$ & 0 & $0.8497(8)$ \\
\hline $\mathrm{C} 13$ & $0.1380(4)$ & 0 & $0.5040(8)$ \\
\hline $\mathrm{C} 14$ & $0.3747(5)$ & 0 & $0.3008(11)$ \\
\hline C15 & $0.2462(5)$ & $0.2463(5)$ & $0.3669(8)$ \\
\hline C16 & $0.3171(4)$ & $0.2449(5)$ & $0.4906(8)$ \\
\hline C17 & $0.1793(4)$ & $0.2496(5)$ & $0.3756(7)$ \\
\hline
\end{tabular}

a Only the set of chlorines with occupancy $=0.50$ is included.

Dimeric copper(II) trichloroacetate adducts may therefore be a suitable choice for a study of the structural factors influencing magnetic properties.

In the course of our studies of dimeric copper(II) trichloroacetate adducts, we prepared two magnetically different modifications of the caffeine adduct, $\left[\mathrm{Cu}\left(\mathrm{CCl}_{3} \mathrm{COO}\right)_{2}(\mathrm{caf})\right]_{2}$, one light green, (2), and the other pale green, (3). A com-
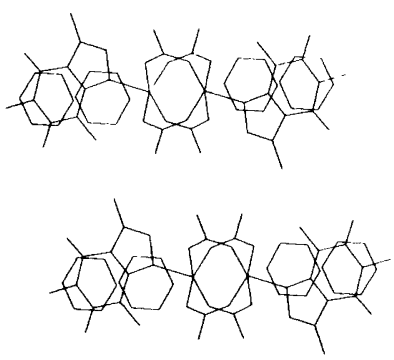
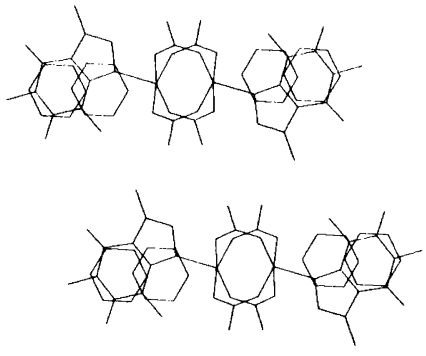

Fig. 2. Stereoview of the dimer $\left[\mathrm{Cu}\left(\mathrm{CCl}_{3} \mathrm{COO}\right)_{2}(\mathrm{caf})\right]_{2} \cdot(2 \mathrm{bz}),(1)$. 
Table 2. Interatomic distances $(\AA \AA)$ and angles $\left(^{\circ}\right)$ with e.s.d.s in parentheses. ${ }^{a}$

\begin{tabular}{|c|c|c|c|}
\hline $\mathrm{Cu}-\mathrm{Cu}^{\prime}$ & $2.852(2)$ & $\mathrm{O} 1-\mathrm{Cu}-\mathrm{O} 1^{*}$ & $88.1(2)$ \\
\hline $\mathrm{Cu}-\mathrm{O} 1$ & $1.987(4)$ & $\mathrm{O} 1-\mathrm{Cu}-\mathrm{O} 2^{*}$ & 88.7(2) \\
\hline $\mathrm{Cu}^{\prime}-\mathrm{O} 2$ & $1.959(4)$ & $\mathrm{O} 2^{\prime}-\mathrm{Cu}-\mathrm{O} 2^{*}$ & $88.6(2)$ \\
\hline $\mathrm{C} 1-01$ & $1.215(5)$ & $\mathrm{O} 1-\mathrm{Cu}-\mathrm{O} 2^{\prime}$ & $161.6(1)$ \\
\hline $\mathrm{C} 1-\mathrm{O} 2$ & $1.245(5)$ & $\mathrm{O} 1-\mathrm{Cu}-\mathrm{N} 9$ & $90.0(2)$ \\
\hline $\mathrm{C} 1-\mathrm{C} 3$ & $1.556(8)$ & $\mathrm{O} 2-\mathrm{Cu}^{\prime}-\mathrm{N} 9^{\prime}$ & $108.1(2)$ \\
\hline C3-Cl1 & $1.760(9)$ & $\mathrm{O} 1-\mathrm{C} 1-\mathrm{O} 2$ & $129.0(6)$ \\
\hline $\mathrm{C} 3-\mathrm{Cl} 2$ & $1.699(8)$ & $\mathrm{Cu}-\mathrm{O} 1-\mathrm{C} 1$ & $127.7(4)$ \\
\hline $\mathrm{C} 3-\mathrm{Cl} 3$ & $1.751(12)$ & $\mathrm{Cu}^{\prime}-\mathrm{O} 2-\mathrm{C} 1$ & $121.6(4)$ \\
\hline $\mathrm{Cu}-\mathrm{N} 9$ & $2.121(5)$ & $\mathrm{O} 1-\mathrm{C} 1-\mathrm{C} 3$ & $114.4(4)$ \\
\hline $\mathrm{N} 1-\mathrm{C} 2$ & $1.391(12)$ & $\mathrm{O} 2-\mathrm{C} 1-\mathrm{C} 3$ & $116.6(4)$ \\
\hline C2-N3 & $1.397(7)$ & $\mathrm{O} 1-\mathrm{Cu}-\mathrm{Cu}^{\prime}$ & $78.1(2)$ \\
\hline N3-C4 & $1.379(11)$ & $\mathrm{O} 2-\mathrm{Cu}^{\prime}-\mathrm{Cu}$ & $83.5(2)$ \\
\hline C4-C5 & $1.370(11)$ & $\mathrm{N} 9-\mathrm{Cu}-\mathrm{Cu}^{\prime}$ & $163.4(3)$ \\
\hline C5-C6 & $1.441(8)$ & $\mathrm{Cu}-\mathrm{N} 9-\mathrm{C} 4$ & $145.9(6)$ \\
\hline C6-N1 & $1.390(13)$ & $\mathrm{Cu}-\mathrm{N} 9-\mathrm{C} 8$ & $112.1(4)$ \\
\hline C5-N7 & $1.359(11)$ & C4-N9-C8 & $102.0(6)$ \\
\hline N7-C8 & $1.373(8)$ & $\mathrm{C} 6-\mathrm{N} 1-\mathrm{C} 2$ & $125.5(5)$ \\
\hline C8-N9 & $1.411(12)$ & C6-N1-C11 & $119.8(7)$ \\
\hline N9-C4 & $1.331(7)$ & $\mathrm{C} 11-\mathrm{N} 1-\mathrm{C} 2$ & $114.7(8)$ \\
\hline C6-O10 & $1.221(10)$ & N1-C2-N3 & $118.5(8)$ \\
\hline $\mathrm{N} 1-\mathrm{C} 11$ & $1.485(9)$ & $\mathrm{N} 1-\mathrm{C} 2-\mathrm{O} 12$ & $120.8(6)$ \\
\hline C2-O12 & $1.227(12)$ & $\mathrm{O} 12-\mathrm{C} 2-\mathrm{N} 3$ & $120.7(9)$ \\
\hline N3-C13 & $1.482(11)$ & C2-N3-C4 & $119.0(7)$ \\
\hline N7-C14 & $1.444(15)$ & $\mathrm{C} 2-\mathrm{N} 3-\mathrm{C} 13$ & $120.9(7)$ \\
\hline C15-C16 & $1.401(9)$ & C13-N3-C4 & $120.2(5)$ \\
\hline $\mathrm{C} 15-\mathrm{C} 17$ & $1.388(13)$ & N3-C4-C5 & $121.1(5)$ \\
\hline $\mathrm{C} 17-\mathrm{C} 16^{\prime}$ & $1.412(12)$ & N3-C4-N9 & $126.5(6)$ \\
\hline $\mathrm{C} 3-\mathrm{Cl} 4$ & $1.870(11)$ & N9-C4-C5 & $112.3(7)$ \\
\hline C3-Cl5 & $1.592(10)$ & $\mathrm{C} 4-\mathrm{C} 5-\mathrm{C} 6$ & $122.9(8)$ \\
\hline $\mathrm{C} 3-\mathrm{Cl} 6$ & $1.717(12)$ & $\mathrm{C} 4-\mathrm{C} 5-\mathrm{N} 7$ & $109.1(5)$ \\
\hline $\mathrm{C} 3-\mathrm{Cl} 7$ & $1.744(17)$ & C6-C5-N7 & $128.0(8)$ \\
\hline $\mathrm{C} 3-\mathrm{Cl} 8$ & $1.780(16)$ & $\mathrm{C} 5-\mathrm{C} 6-\mathrm{N} 1$ & $112.9(7)$ \\
\hline C3-C19 & $1.722(28)$ & C5-C6-O10 & $125.8(9)$ \\
\hline & & O10-C6-N1 & $121.3(6)$ \\
\hline & & C5-N7-C8 & $103.7(7)$ \\
\hline & & $\mathrm{C} 5-\mathrm{N} 7-\mathrm{C} 14$ & 129.4(6) \\
\hline & & C14-N7-C8 & $126.9(8)$ \\
\hline & & N7-C8-N9 & $112.9(7)$ \\
\hline & & C16-C15-C17 & $120.1(8)$ \\
\hline & & C15-C17-C16' & $119.9(6)$ \\
\hline & & $\mathrm{C} 17^{\prime}-\mathrm{C} 16-\mathrm{C} 15$ & $120.0(8)$ \\
\hline & & $\mathrm{C} 1-\mathrm{C} 3-\mathrm{Cl}$ & $110.7(5)$ \\
\hline & & $\mathrm{C} 1-\mathrm{C} 3-\mathrm{Cl} 2$ & $115.6(4)$ \\
\hline & & $\mathrm{C} 1-\mathrm{C} 3-\mathrm{Cl} 3$ & $106.4(5)$ \\
\hline & & $\mathrm{Cl} 1-\mathrm{C} 3-\mathrm{Cl} 2$ & $110.3(5)$ \\
\hline & & $\mathrm{Cl} 1-\mathrm{C} 3-\mathrm{Cl} 3$ & $106.2(5)$ \\
\hline & & $\mathrm{Cl} 2-\mathrm{C} 3-\mathrm{Cl} 3$ & $107.0(6)$ \\
\hline
\end{tabular}

a Primed atoms are related to atoms in the asymmetric unit (Table 1) by the molecular centre of symmetry. Atoms marked \# are likewise related by the molecular mirror plane to those of Table 1 and by the molecular centre of symmetry to the starred $\left({ }^{*}\right)$ atoms. 
HORIE ET AL.

Table 3. Best planes in the dimer.

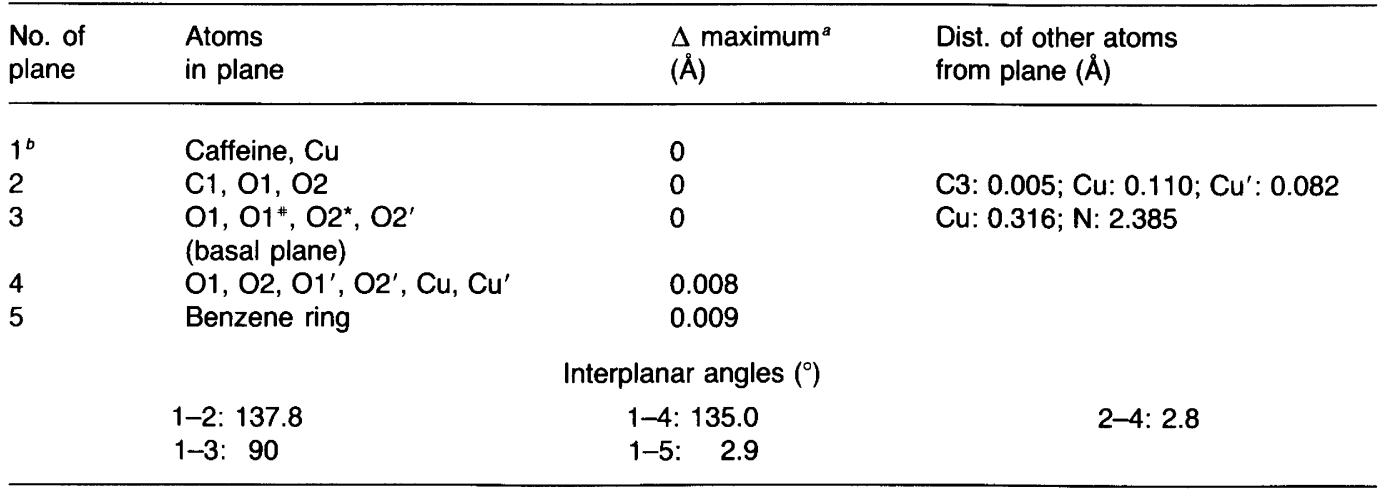

${ }^{a}$ Maximum devn. of constituent atoms from plane. ${ }^{b}$ Crystallographic mirror plane.

plex $\left[\mathrm{Cu}\left(\mathrm{CCl}_{3} \mathrm{COO}\right)_{2}(\mathrm{caf})\right]_{2} \cdot(2 \mathrm{bz}),(1)$, where bz $=$ benzene, was also isolated. These three complexes all display a dimer type of antiferromagnetism. For both (1) and (2) a change in magnetic properties at ca. $200 \mathrm{~K}$ is observed, indicating a phase transition. Hence, the crystal structure of the benzene adduct was determined by $\mathrm{X}$-ray diffraction in order to clarify the structure and to

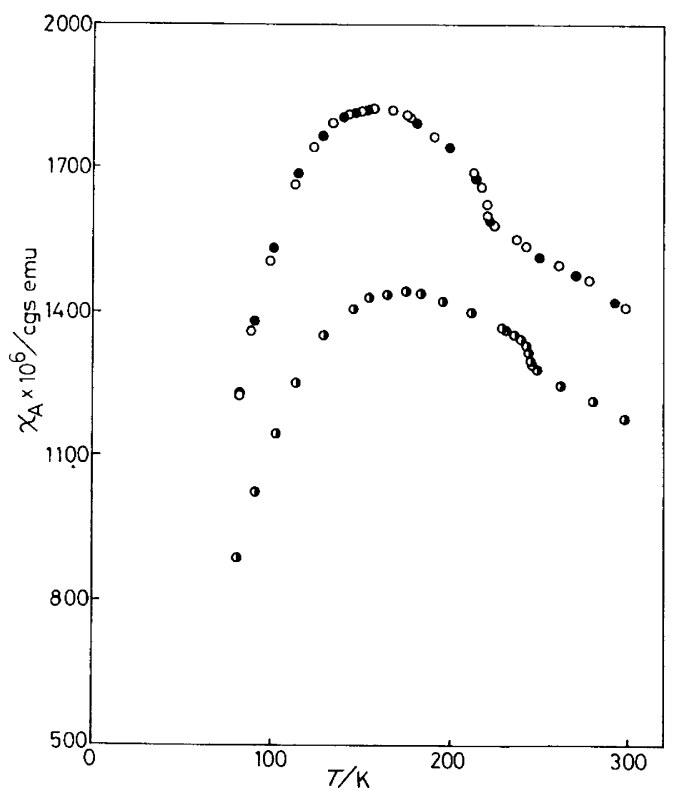

Fig. 3. Variation of magnetic susceptibilities with temperature. (O) Sample $A$ and $(O) B$ of the light green form of $\left[\mathrm{Cu}\left(\mathrm{CCl}_{3} \mathrm{COO}\right)_{2}(\mathrm{caf})\right]_{2},(2) ;(0)$ $\left[\mathrm{Cu}\left(\mathrm{CCl}_{3} \mathrm{COO}\right)_{2}(\mathrm{caf})\right]_{2} \cdot(2 \mathrm{bz}),(1)$. the magnetic properties in more detail in relation to the structure.

\section{Experimental}

Syntheses. $\left[\mathrm{Cu}\left(\mathrm{CCl}_{3} \mathrm{COO}\right)_{2}(\mathrm{caf})\right]_{2} \cdot(2 \mathrm{bz}),(1): \mathrm{A}$ solution of caffeine $(1 \mathrm{mmol})$ in benzene $(20 \mathrm{ml})$

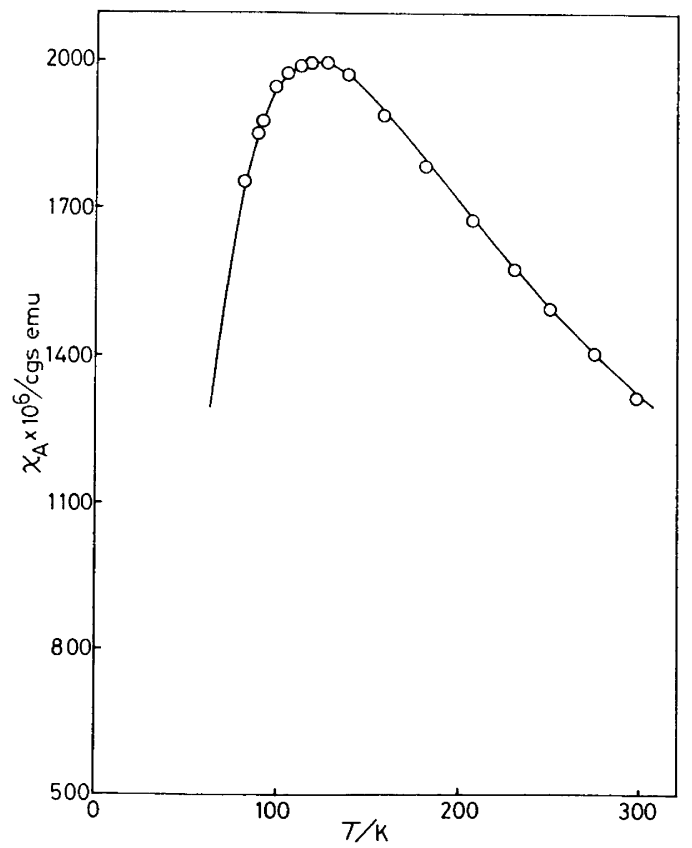

Fig. 4. Variation of magnetic susceptibilities with temperature. (O) Pale green form of $\left[\mathrm{Cu}\left(\mathrm{CCl}_{3} \mathrm{COO}\right)_{2}\right.$ (caf) $]_{2}$, (3). Solid line shows calculated susceptibilities. 
Table 4. Magnetic susceptibilities ${ }^{a}$ for $\left[\mathrm{Cu}\left(\mathrm{CCl}_{3} \mathrm{COO}\right)_{2}\right.$ (caf) $]_{2}$, light green form, (2). $\chi_{\text {dia }}=-272 \times 10^{-6} \mathrm{cgs}$ emu.

\begin{tabular}{|c|c|c|c|}
\hline Sample A & $10^{6} \chi_{\mathrm{A}}$ & $\begin{array}{l}\text { Sampl } \\
T / \mathrm{K}\end{array}$ & $10^{6} \chi_{\mathrm{A}}$ \\
\hline \multicolumn{2}{|c|}{ Low temp. region } & \multicolumn{2}{|c|}{ Low temp. region } \\
\hline 81.3 & 1225 & 81.4 & 1228 \\
\hline 88.3 & 1359 & 90.1 & 1383 \\
\hline 98.1 & 1507 & 100.0 & 1540 \\
\hline 112.1 & 1667 & 114.8 & 1689 \\
\hline 123.4 & 1748 & 128.1 & 1773 \\
\hline 133.6 & 1801 & 139.9 & 1807 \\
\hline 143.2 & 1817 & 146.2 & 1817 \\
\hline 150.3 & 1826 & 153.9 & 1822 \\
\hline 156.8 & 1824 & 178.3 & 1793 \\
\hline 166.4 & 1821 & 198.3 & 1745 \\
\hline 176.1 & 1807 & & \\
\hline 177.6 & 1803 & \multicolumn{2}{|c|}{ Intermediate temp. region } \\
\hline 190.9 & 1771 & 214.2 & 1680 \\
\hline 212.6 & 1696 & 221.2 & 1590 \\
\hline \multicolumn{2}{|c|}{ Intermediate temp. region } & \multicolumn{2}{|c|}{ High temp. region } \\
\hline 216.0 & 1680 & 250.3 & 1519 \\
\hline 217.0 & 1659 & 270.2 & 1476 \\
\hline 220.1 & 1626 & 292.0 & 1416 \\
\hline 221.8 & 1600 & & \\
\hline 224.3 & 1582 & & \\
\hline \multicolumn{4}{|c|}{ High temp. region } \\
\hline 237.5 & 1555 & & \\
\hline 243.4 & 1542 & & \\
\hline 260.0 & 1508 & & \\
\hline 260.6 & 1505 & & \\
\hline 278.1 & 1473 & & \\
\hline 298.0 & 1414 & & \\
\hline
\end{tabular}

${ }^{a}$ Magnetic susceptibilities $\left(\chi_{A}\right)$ and diamagnetic corrections $\left(\chi_{\text {dia }}\right)$ are given in cgs emu $\mathrm{mol}^{-1}(1 \mathrm{cgs}$ emu $\mathrm{mol}^{-1}=4 \pi 10^{-6} \mathrm{~m}^{3} \mathrm{~mol}^{-1}$ ).

was added to a solution of $\mathrm{Cu}\left(\mathrm{CCl}_{3} \mathrm{COO}\right)_{2} \cdot 3 \mathrm{H}_{2} \mathrm{O}$ $(1 \mathrm{mmol})$ in benzene $(20 \mathrm{ml})$ and 2,2-dimethoxypropane $(1 \mathrm{ml})$. The greenish-brown precipitate which formed after a few min was filtered off and the product recrystallized by adding benzene slowly to an acetonitrile solution of the complex. After washing with petroleum ether, the crystals were dried in vacuo at room temperature. Anal. $\mathrm{C}_{18} \mathrm{H}_{16} \mathrm{~N}_{4} \mathrm{O}_{6} \mathrm{Cl}_{6} \mathrm{Cu}: \mathrm{C}, \mathrm{H}, \mathrm{N}, \mathrm{Cu}$.

$\left[\mathrm{Cu}\left(\mathrm{CCl}_{3} \mathrm{COO}\right)_{2} \text { (caf) }\right]_{2}$ (light green form), (2): This compound was prepared in the same way as above, using toluene instead of benzene. Anal. $\mathrm{C}_{12} \mathrm{H}_{10} \mathrm{~N}_{4} \mathrm{O}_{6} \mathrm{Cl}_{6} \mathrm{Cu}: \mathrm{C}, \mathrm{H}, \mathrm{N}, \mathrm{Cu}$.

$\left[\mathrm{Cu}\left(\mathrm{CCl}_{3} \mathrm{COO}\right)_{2} \text { (caf) }\right]_{2}$ (pale green form), (3): A solution of caffeine $(1 \mathrm{mmol})$ in chloroform $(10$ $\mathrm{ml})$ was added to a solution of $\mathrm{Cu}\left(\mathrm{CCl}_{3} \mathrm{COO}\right)_{2}$. $3 \mathrm{H}_{2} \mathrm{O}(1 \mathrm{mmol})$ in chloroform $(20 \mathrm{ml})$ and $2,2-$ dimethoxypropane $(1 \mathrm{ml})$. After the resulting solution had been concentrated to one-third of its volume, it was allowed to stand overnight at ca. $5^{\circ} \mathrm{C}$ in a refrigerator. The pale green crystals were collected, washed with petroleum ether and dried in vacuo at room temperature. Anal. $\mathrm{C}_{12} \mathrm{H}_{10} \mathrm{~N}_{4} \mathrm{O}_{6} \mathrm{Cl}_{6} \mathrm{Cu}: \mathrm{C}, \mathrm{H}, \mathrm{N}, \mathrm{Cu}$.

Magnetic measurements. Magnetic susceptibilities in the temperature range $80-300 \mathrm{~K}$ were determined by the Faraday method. The correction for diamagnetic contribution $\left(\chi_{\text {dia }}\right)$ was made by use of Pascal's constants. ${ }^{5}$ The cryomagnetic data were fitted to the Bleaney-Bowers eqn. (1) allowing for the presence of paramagnetic impurity, ${ }^{6}$ where $P$ is the mole fraction of the monomeric copper(II) impurity, $g_{\mathrm{i}}$ is the average $g$ factor for the impurity, and the other symbols have their usual meanings. The values $g_{\mathrm{i}}=2.2$ and $N \alpha$ $=60 \times 10^{-6} \mathrm{cgs}$ emu were used throughout the present study. The best-fit parameters, $-2 J, g$, and $P$, were obtained by using a non-linear least-

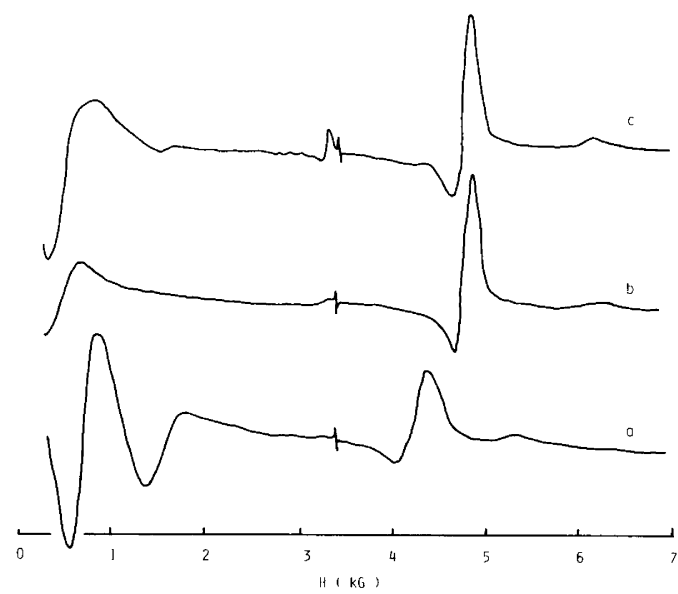

Fig. 5. Room temperature polycrystalline powder EPR spectra at $X$-band frequency. (a) Pale green form of $\left[\mathrm{Cu}\left(\mathrm{CCl}_{3} \mathrm{COO}\right)_{2} \text { (caf) }\right]_{2}$, (3). (b) Light green form of $\left[\mathrm{Cu}\left(\mathrm{CCl}_{3} \mathrm{COO}\right)_{2}(\mathrm{caf})\right]_{2}$, (2).

(c) $\left[\mathrm{Cu}\left(\mathrm{CCl}_{3} \mathrm{COO}\right)_{2}(\mathrm{caf})\right]_{2} \cdot(2 \mathrm{bz}),(1)$. The small features near $3.3 \mathrm{kG}$ are due to monomeric $\mathrm{Cu}(\mathrm{II})$ impurities. 
squares program, SALS (version D), written by T. Nakagawa (The University of Tokyo) and Y. Oyanagi (The University of Tsukuba), with a FACOM M-200 computer at the Nagoya University Computation Center. As a convenient statistical indicator of the quality of the least-squares fits, the discrepancy index, $\sigma_{\text {dis }}=$ $\left[\Sigma\left(\chi_{\text {obsd }}-\chi_{\text {caldd }}\right)^{2} / \Sigma \chi_{\text {obsd }}{ }^{2}\right]^{1 / 2}$ was employed. The magnetic susceptibility data are presented in Tables 4-6 and shown in Figs. 3 and 4 as plots of $\chi_{A}$ vs. $T$. The values of $-2 J, g, P$, and $\sigma_{\mathrm{dis}}$ are summarized in Table 7.

$$
\begin{aligned}
\chi & =\frac{N g^{2} \beta^{2}}{3 k T}\left[1+\frac{1}{3} \exp \left(\frac{-2 J}{k T}\right)\right]^{-1}(1-P) \\
& +\frac{N g_{i}^{2} \beta^{2}}{4 k T} P+N \alpha
\end{aligned}
$$

EPR spectra. Polycrystalline powder EPR spectra were recorded on a Jeol JES-ME-2 spectrometer in the X-band range, and are shown in Figs. 5-7. The EPR parameters are given in Table 8.

$X$-ray crystallography. X-ray data were collected with an Enraf-Nonius CAD-4 automated diffractometer by Molecular Structure Corporation, College Station, Texas. A green, prismatic crystal of dicaffeinetetrakis( $\mu$-trichloroacetato)dicopper(II) benzene solvate, (1), having approximate dimensions $0.50 \times 0.20 \times 0.15 \mathrm{~mm}$ was mounted

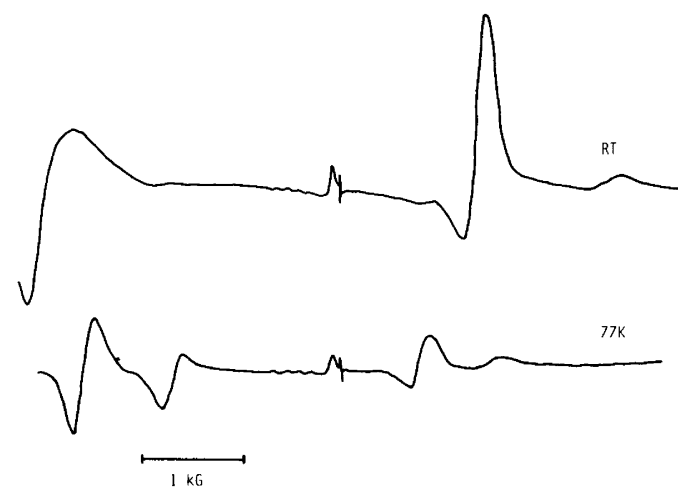

Fig. 6. X-band polycrystalline powder EPR spectra of the light green form of $\left[\mathrm{Cu}\left(\mathrm{CCl}_{3} \mathrm{COO}\right)_{2}(\mathrm{caf})\right]_{2}$, (2), at room temperature (RT) and liquid nitrogen temperature $(77 \mathrm{~K})$. The small features near $3.3 \mathrm{kG}$ are due to monomeric $\mathrm{Cu}(\mathrm{II})$ impurities.
Table 5. Magnetic susceptibilities ${ }^{a}$ for $\left[\mathrm{Cu}\left(\mathrm{CCl}_{3} \mathrm{COO}\right)_{2}(\mathrm{caf})\right]_{2} \cdot(2 \mathrm{bz}),(1) \cdot \chi_{\text {dia }}=-326.9 \times 10^{-6}$

\begin{tabular}{|c|c|}
\hline$T / K$ & $10^{6} \chi_{\mathrm{A}}$ \\
\hline \multicolumn{2}{|c|}{ Low temp. region } \\
\hline 81.5 & 893.0 \\
\hline 91.8 & 1031.6 \\
\hline 102.3 & 1147.2 \\
\hline 113.9 & 1256.3 \\
\hline 129.7 & 1351.3 \\
\hline 145.3 & 1410.4 \\
\hline 154.1 & 1433.5 \\
\hline 164.2 & 1441.2 \\
\hline 174.3 & 1446.3 \\
\hline 183.1 & 1442.5 \\
\hline 196.2 & 1425.8 \\
\hline 212.2 & 1402.7 \\
\hline 230.1 & 1368.0 \\
\hline 232.1 & 1368.0 \\
\hline 235.1 & 1357.7 \\
\hline 236.1 & 1356.4 \\
\hline 237.0 & 1353.9 \\
\hline 239.0 & 1350.0 \\
\hline \multicolumn{2}{|c|}{ Intermediate temp. region } \\
\hline 242.2 & 1330.8 \\
\hline 244.2 & 1315.4 \\
\hline 245.0 & 1301.2 \\
\hline 248.0 & 1300.0 \\
\hline \multicolumn{2}{|c|}{ High temp. region } \\
\hline 250.1 & 1288.4 \\
\hline 262.0 & 1249.9 \\
\hline 280.0 & 1219.1 \\
\hline 298.0 & 1181.8 \\
\hline
\end{tabular}
cgs emu.

${ }^{a}$ See footnote to Table 4.

on a glass fiber and $\mathrm{Cu} K \alpha$ radiation was used for data collection. Cell constants were determined from setting angles of 25 reflections in the range $5<\theta<22^{\circ}$. Based on systematic absences of $h k l: h+k=2 n+1$, the space group could be $C 2$, $C m$ or $C 2 / m$ (Nos. 5,8 or 12). Statistical tests indicated centrosymmetry. Intensities of 2564 unique reflections were collected out to $2 \theta<140^{\circ}$ using $\omega-2 \theta$ scans, with scan rate 2 to $20^{\circ} \mathrm{min}^{-1}$ in $\omega$, and with $\theta$ scan width $=(0.8+0.30 \tan \theta)^{\circ}$. Of the reflections collected, 460 had $I \leq 0.5 \sigma(I)$ and were discarded, as well as an additional 216 reflections with $F \leq \sigma(F)$. Three standard reflections were measured every $41 \mathrm{~min}$. During data col- 
Table 6. Magnetic susceptibilities ${ }^{a}$ for $\left[\mathrm{Cu}\left(\mathrm{CCl}_{3} \mathrm{COO}\right)_{2}\right.$ (caf) $]_{2}$, pale green form, (3). $\chi_{\text {dia }}=-272 \times 10^{-6} \mathrm{cgs}$ emu.

\begin{tabular}{rr}
\multicolumn{1}{c}{$T / \mathrm{K}$} & $10^{6} \chi_{\mathrm{A}}$ \\
\hline 81.4 & 1758 \\
88.3 & 1852 \\
88.8 & 1861 \\
91.0 & 1881 \\
98.9 & 1949 \\
105.7 & 1981 \\
112.3 & 1996 \\
117.7 & 2003 \\
126.3 & 2003 \\
138.2 & 1973 \\
158.7 & 1894 \\
181.9 & 1788 \\
206.6 & 1679 \\
230.0 & 1579 \\
250.6 & 1499 \\
275.1 & 1408 \\
298.8 & 1321 \\
\hline
\end{tabular}

aSee footnote to Table 4.

lection, there was a loss in intensity for the three reflections of ca. $6 \%$. A linear decay correction was therefore applied. Corrections were made. for Lorentz, polarization and absorption effects (abs. corrn. empirical; min. transm. coeff. = 0.147 , max. $=0.440$ ). Programs used came from SHELX $76,{ }^{7}$ modified for a PDP 1144 computer.

The structure was solved by conventional heavy-atom methods and refined by successive

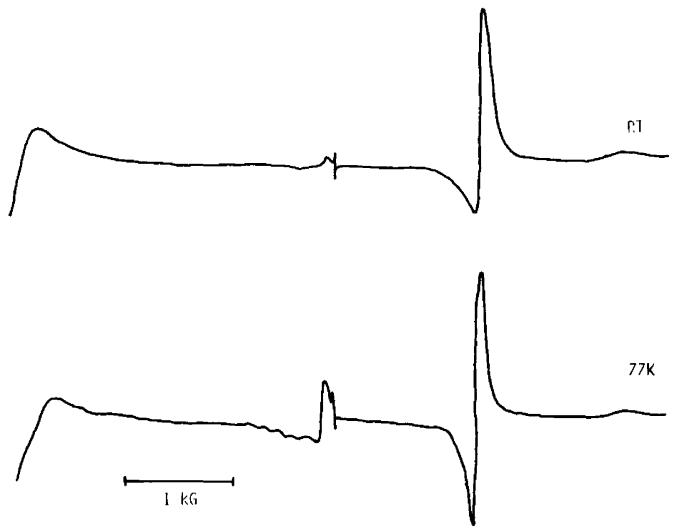

Fig. 7. X-band polycrystalline powder EPR spectra of $\left[\mathrm{Cu}\left(\mathrm{CCl}_{3} \mathrm{COO}\right)_{2}(\mathrm{caf})\right]_{2} \cdot(2 \mathrm{bz}),(1)$, at room temperature (RT) and liquid nitrogen temperature $(77 \mathrm{~K})$. The small features near $3.3 \mathrm{kG}$ are due to monomeric $\mathrm{Cu}$ (II) impurities.

experimentally weighted least-squares iterations assuming the correct space group to be $C 2 / \mathrm{m}$. It soon became apparent that the trichloromethyl groups were disordered. This is, however, quite common for trihaloacetates. ${ }^{4,8,9} \mathrm{~A}$ model with a main orientation of the three chlorines (occupancy $50 \%$ ) and two other orientations (occ. $25 \%$ each) corresponding to rotations of ca. $35^{\circ}$ and $20^{\circ}$ around the $\mathrm{C}-\mathrm{CCl}_{3}$ bond (to each side of the main orientation) seemed to work best, and the successful refinement justified the choice of space group. Absence of high $U_{22}$ values for $\mathrm{Cu}$ and for atoms in caffeine also supports the idea

Table 7. Magnetic data.

\begin{tabular}{|c|c|c|c|c|c|c|c|}
\hline Compound & $-2 \mathrm{~J} / \mathrm{cm}^{-1}$ & $g$ & $P \times 10^{2}$ & $\sigma \times 10^{3 b}$ & $-2 \mathrm{~J} / \mathrm{cm}^{-1}$ & $g$ & $\sigma \times 10^{3 b}$ \\
\hline \multicolumn{8}{|l|}{ (1) } \\
\hline Low temp. region & 202.7 & 2.265 & 4.58 & 1.57 & 184.6 & 2.216 & 14.5 \\
\hline High temp. region & - & - & - & - & 194.5 & 2.223 & 3.87 \\
\hline \multicolumn{8}{|l|}{ (2) } \\
\hline \multicolumn{8}{|l|}{ Low temp. region } \\
\hline Sample A & 177.5 & 2.421 & 2.85 & 2.71 & 169.2 & 2.388 & 5.34 \\
\hline Sample B & 176.5 & 2.412 & 2.66 & 1.31 & 168.8 & 2.380 & 5.16 \\
\hline \multicolumn{8}{|l|}{ High temp. region } \\
\hline Sample A & - & - & - & - & 207.6 & 2.484 & 2.56 \\
\hline Sample B & - & - & - & - & 200.6 & 2.452 & 1.82 \\
\hline (3) & 135.7 & 2.222 & 1.88 & 1.54 & - & - & - \\
\hline
\end{tabular}

${ }^{a} \mathrm{~N} \alpha=60 \times 10^{-6} \mathrm{cgs}$ emu(fix.). ${ }^{b} \mathrm{~N} \alpha=60 \times 10^{-6} \mathrm{cgs}$ emu(fix.) and $P=0$ (fix.) 
HORIE ET AL.

Table 8. EPR parameters.

\begin{tabular}{|c|c|c|c|c|c|}
\hline Compound & $g_{\|}$ & $g_{\perp}$ & $g_{\mathrm{av}}{ }^{a}$ & $|D| / \mathrm{cm}^{-1}$ & $H_{0} / \mathrm{cm}^{-1}$ \\
\hline \multicolumn{6}{|l|}{ (1) } \\
\hline Room temp. & 2.488 & 2.142 & 2.263 & .372 & .316 \\
\hline $77 \mathrm{~K}$ & 2.389 & 2.139 & 2.225 & .220 & .306 \\
\hline \multicolumn{6}{|l|}{ (2) } \\
\hline Room temp. & 2.468 & 2.109 & 2.235 & .366 & .316 \\
\hline $77 \mathrm{~K}$ & 2.454 & 2.102 & 2.225 & .367 & .306 \\
\hline \multicolumn{6}{|l|}{ (3) } \\
\hline Room temp. & 2.317 & 2.143 & 2.203 & .237 & .316 \\
\hline $77 \mathrm{~K}$ & 2.305 & 2.152 & 2.204 & .223 & .306 \\
\hline
\end{tabular}

${ }^{a} g_{\mathrm{av}}=\left(1 / 3\left(g_{\|}^{2}+2 g_{1}^{2}\right)\right)^{1 / 2}$.

that those atoms lie on a mirror plane as required by $C 2 / m($ or $C m$ ). Attempts at refinements in the alternative space groups gave no apparent improvement according to Hamilton's test. ${ }^{10}$ Also, both the disorder in $\mathrm{CCl}_{3}$ and the high symmetry of the dimer were found to persist in the noncentric space groups.

The hydrogen atoms were not included in the refinement. The other atoms were refined anisotropically, and refinement terminated when all parameter shifts were less than 0.06o. The quantity minimized was $\Sigma w\left(F_{\mathrm{o}}-F_{\mathrm{c}}\right)^{2}$ where $w=$ $1 / \sigma^{2}\left(F_{0}\right), \quad \sigma\left(F_{0}\right)=\sigma(I) / 2 F_{0}$ Lp and $\sigma(I)=$ $T\left(C+R^{2} B\right)^{1 / 2}+0.005 F_{\mathrm{o}}^{2} . T$ is the scan rate, $R$ is the ratio of scan time to background counting time and $B$ is the total background count. A final difference electron density map showed no maxima above $0.7 \mathrm{e}^{-} \AA^{-3}$. Final $R=0.068, R_{\mathrm{w}}=$ 0.082 and $S=2.05$. Atomic coordinates are given in Table 1, interatomic distances and angles are listed in Table 2, and molecular planes are listed in Table $3 .^{*}$ Scattering factors used were taken from Cromer and Liberman, ${ }^{11}$ Cromer and Mann $^{12}$ and Stewart, Davidson and Simpson. ${ }^{13}$

\section{Results and discussion}

Fig. 1 shows the structure of the dimer, $\left[\mathrm{Cu}\left(\mathrm{CCl}_{3} \mathrm{COO}\right)_{2}\left(\mathrm{C}_{8} \mathrm{H}_{10} \mathrm{~N}_{4} \mathrm{O}_{2}\right)\right]_{2} \cdot 2 \mathrm{C}_{6} \mathrm{H}_{6}$, (1). The

\footnotetext{
*Tables of observed and calculated structure factors, temperature factors and coordinates of the chlorine atoms with occupancy $=0.25$ are available from the authors E.A.M. or S.H. upon request.
}

benzene molecules as well as the chlorines are left out for the sake of clarity. With $Z$ being 2 , the space group symmetry requires the molecule to have $2 / m$ symmetry.

The $\mathrm{Cu}$ coordination. Each copper atom has a distorted, square pyramidal coordination sphere, with four coplanar oxygen atoms (Table 3) constituting the basal plane and N9 of the caffeine molecule at the apex. This is the standard conformation of $\left[\mathrm{Cu}(\mathrm{RCOO})_{2} \mathrm{~L}\right]_{2}$ dimers. ${ }^{14,15}$ Like other dimers, (1) has a short $\mathrm{Cu}---\mathrm{Cu}$ contact trans to the $\mathrm{Cu}-\mathrm{L}(\mathrm{N} 9)$ bond. While this contact is mostly in the range $2.56-2.67 \AA$ in classical copper acetate dimers, ${ }^{2,15}$ in (1), this distance is $2.852(2) \AA$ and may be compared to 2.886(4), 2.766(3) and 2.732(av.) $\AA$, the $\mathrm{Cu}-\mathrm{Cu}$ distances found in the dimers with $\mathrm{R}=\mathrm{CF}_{3}$ and $\mathrm{L}=$ quinoline, ${ }^{9} \mathrm{R}=$ $\mathrm{CCl}_{3}$ or $\mathrm{CBr}_{3}$ and $\mathrm{L}=2$-chloropyridine, ${ }^{1,16}$ and $\mathrm{R}$ $=\mathrm{CCl}_{3}$ and $\mathrm{L}=$ benzonitrile, ${ }^{3}$ respectively. Also, dimers with $\mathrm{R}=\mathrm{CH}_{2} \mathrm{X}(\mathrm{X}=\mathrm{F}, \mathrm{Cl})$ may have distances above $2.7 \AA . .^{15}$ Earlier studies have shown that the $\mathrm{Cu}-\mathrm{Cu}$ separation in such dimers increases with increasing strength of the parent bridging carboxylic acid. ${ }^{17}$ Increasing $\mathrm{Cu}-\mathrm{Cu}$ separation is known to be attended by increasing distance of $\mathrm{Cu}$ from the basal four-oxygen plane. ${ }^{9,15}$ The present investigation provides no exception to that rule, with $\mathrm{Cu}$ being $0.32 \AA$ above the plane. The $\mathrm{Cu}-\mathrm{N}$ and average $\mathrm{Cu}-\mathrm{O}$ bond lengths of 2.12(5) and $1.973 \AA$ are normal. ${ }^{15} \mathrm{Ex}^{-}$ cept for the chlorines, the bridging trichloroacetate ligands are nearly planar, with $\mathrm{C} 1-\mathrm{O} 1$ and $\mathrm{C} 1-\mathrm{O} 2$ being $1.215(5)$ and $1.245(5) \AA$, respectively. Also, the $\mathrm{Cu}-\mathrm{O}-\mathrm{C} 1$ angles are asymmet- 
ric, being $127.7(4)^{\circ}$ for $\mathrm{O} 1$ and $121.6(4)$ for $\mathrm{O} 2$. Angle $\mathrm{O} 1-\mathrm{C} 1-\mathrm{O} 2$ is $129.0(6)^{\circ}$. The literature reports a wide variation in these angles,${ }^{15}$ and the flexibility of such carboxylate bridges is considerable. $^{8}$

The $\mathrm{Cu}^{\prime}-\mathrm{Cu}-\mathrm{N} 9$ angle is only $163.4(3)^{\circ}$. This deviation from linearity is greater than that normally found in copper carboxylate dimers and is probably due to repulsion between the caffeine $\mathrm{C} 13$ methyl group on one side and $\mathrm{Cu}$ plus the $\mathrm{Cl}$ atoms of the bridging ligands $(\mathrm{Cu}---\mathrm{C} 13=3.56 \AA$ and $\mathrm{Cl} 3--\mathrm{C} 13=3.95 \AA$ ) on the other. This is also reflected in the large $\mathrm{Cu}-\mathrm{N} 9-\mathrm{C} 4$ angle of $145.9(6)^{\circ}$, which is $13^{\circ}$ greater than the corresponding angle found when a similar ligand, but with $\mathrm{H}$ instead of $\mathrm{C} 13$ methyl, is bonded to cobalt. ${ }^{18}$ It may also be mentioned here that in the dichlorotriammine(caffeine)ruthenium(III) cation, such a repulsion (involving metal and $\mathrm{C} 13$ methyl) forces Ru to bind to the $\mathrm{C} 8$ atom of caffeine rather than to the expected site, N9. ${ }^{19,20}$

The caffeine ligand. Its structure is similar to those of free and protonated caffeines and similar purines. ${ }^{19,21-26}$ The greatest differences are found in the five-membered ring. Compared to the most accurate caffeine structure, ${ }^{22}$ the $\mathrm{C} 5-\mathrm{N} 7$ and C4-N9 bonds in (1) are $0.03 \AA$ shorter and the N7-C8 and N9-C8 bonds are 0.03 and $0.07 \AA$ longer. The angles also change, notably C4-N9-C8 which has the very low value of 102.0 $(6)^{\circ}$ in $(1)$. All caffeine angles correspond to $s p^{2}$ hybridization of the ring atoms and the bond lengths indicate delocalized $\pi$ bonding involving those atoms. The complete planarity of the ligand (except for methyl hydrogens) is not unexpected. Purine derivatives are nearly planar with C4-C5 twist angles of only a few degrees. ${ }^{19,21-26}$ The caffeine ligands are staggered with respect to the $\mathrm{Cu}-\mathrm{O}$ bonds.

Molecular packing. The benzene plays an important role in the packing of the molecules (Fig. 2). Each dimer may be viewed as consisting of a $\mathrm{Cu}_{2}\left(\mathrm{CCl}_{3} \mathrm{COO}\right)_{4}$ box-like part with a flat caffeine part attached at each end. Since the dimer is centrosymmetric, the thickness of the box (in the $b$ direction) is $b / 2 \approx 7 \AA$, roughly twice that of the caffeine part. Such a molecule is not easy to pack effectively and this may be the reason why the unsolvated dimer, (2), forms only a microcrystalline residue. However, in (1), the benzene molecules are stacked so that each caffeine ligand is sandwiched between two benzenes in the $b$ direction, and vice versa. Since the benzenes are also located at centres of symmetry $b / 2$ apart, the thickness of the caffeine ends of the dimer now effectively also becomes $b / 2 \approx 7 \AA$.

The stacking of the molecules in this manner is obviously quite effective. Since the benzenes are almost parallel with the caffeine ligands and the distance between the two are ca. 3.4-3.6 $\AA$, there may be a weak charge-transfer interaction holding them together.

Magnetic properties. The phase transition temperature for $\left[\mathrm{Cu}\left(\mathrm{CCl}_{3} \mathrm{COO}\right)_{2}(\mathrm{caf})\right]_{2} \cdot(2 \mathrm{bz}),(1)$, ca. $245 \mathrm{~K}$, is higher by about $25 \mathrm{~K}$ than that for the light green form of $\left[\mathrm{Cu}\left(\mathrm{CCl}_{3} \mathrm{COO}\right)_{2}(\mathrm{caf})\right]_{2}$, (2). The variable-temperature magnetic susceptibilities for low and high temperature regions of these complexes in Tables 4 and 5 are well reproduced by eqn. (1). In order to make sure that the observed phase transition in these complexes is real, magnetic measurements were made on two samples (A and B) of (2) (Table 4 and Fig. 3). In the low temperature region, the magnetic parameters obtained for the two samples coincided well, indicating that the observed novel transition of the caffeine adducts is genuine (Table 7). In the high temperature region, however, leastsquares fittings with significant results were obtained only by setting $P=0$ in eqn. (1). This is presumably due to the fact that fewer susceptibility data were collected in this region as compared to the low temperature region. As is seen from Table 7, setting $P=0$ tends to decrease the values of $-2 J$ and $g$. Comparison of the magnetism of these complexes in the low and high temperature regions should therefore be made only with the parameters obtained by setting $P=0$. The low temperature $-2 J$ value for $(1)$ was somewhat larger than that for (2), while in the high temperature region, a lower $-2 J$ value was observed for (1). The $-2 J$ value for the pale green form of (caf) adduct, (3), $135 \mathrm{~cm}^{-1}$, is quite small compared with those of (1) and (2). The EPR spectral features of (3) are quite different from the room temperature spectra of (1) and (2) (Fig. 5). They are fundamentally the same as those observed for $\left[\mathrm{Cu}\left(\mathrm{CPh}_{3} \mathrm{COO}\right)_{2}(\mathrm{py})\right]_{2} \cdot(\mathrm{bz}):\left(-2 J=184 \mathrm{~cm}^{-1}\right.$, $\mathrm{Cu}-\mathrm{Cu}=3.086 \AA$ ), whose structure has recently been determined by Steward $e t$ al. and found to have a trigonal-bipyramidal metal geometry. ${ }^{27}$ 
For these two complexes, an unfamiliar relation, $D<H_{0}$, was observed, ${ }^{27-29}$ and this relation has been revealed for a number of copper(II) trichloroacetate adducts whose $-2 J$ values are quite small compared with those of the common copper(II) carboxylates $\left(-2 J \approx 300 \mathrm{~cm}^{-1}\right)^{30}$ which have square-pyramidal metal geometry and obey the common relation $\mathrm{D}>\mathrm{H}_{0}{ }^{31}$ Stepwise variabletemperature EPR measurements on (2) were repeated between room temperature and liquid nitrogen temperature. However, no particular spectral change could be detected between the two extreme temperatures (Fig. 6). On the other hand, the EPR spectral features of (1) at liquid nitrogen temperature were quite different from those at room temperature (Fig. 7): The lowtemperature EPR spectrum appears to be essentially the same as the room-temperature EPR spectrum of (3) accompanying the uncommon relation, $D<H_{0}$ (Table 8). The spectral interconversion accompanied by $D \gtrless H_{0}$ thus takes place reversibly. This interesting finding prompted us to attempt a low-temperature structural study of (1). However, the crystals cracked upon cooling and were thus rendered unsuitable for an X-ray crystallographic investigation. From the magnetic data above it may be speculated that the structure of (3) perhaps has the copper atoms in a trigonal-bipyramidal environment, and from the EPR data one may guess at the possibility of such an environment also for the low-temperature form of (1). The $g$ values obtained by EPR are smaller than those obtained by the magnetic susceptibility measurements (Tables 7 and 8). This is often observed for copper(II) carboxylate dimers. ${ }^{32}$

Acknowledgements. Support for this investigation by the Robert A. Welch Foundation of Houston, Texas, the Norwegian Research Council for Science and the Humanities, and the National Science Foundation, USA (INT-8217957), is gratefully acknowledged.

\section{References}

1. Moreland, J. A. and Doedens, R. J. Inorg. Chem. 17 (1978) 674.

2. Rao, V. M., Sathyanarayana, D. N. and Manohar, H. J. Chem. Soc. Dalton Trans. (1983) 2167.

3. Nakashima, M., Mikuriya, M. and Muto, Y. Bull. Chem. Soc. Jpn. 58 (1985) 968.

4. Porter, L. C., Dickman, M. H. and Doedens, R. J. Inorg. Chem. 22 (1983) 1962.

5. Selwood, P. W. Magnetochemistry, Interscience Publishers, New York 1956, pp. 78 and 91.

6. Ginsberg, A. P. Inorg. Chem. Acta Rev. 5 (1971) 45.

7. Sheldrick, G. M. SHELX 76. A Program for Crystal Structure Determination, University of Cambridge, England 1976.

8. Porter, L. C. and Doedens, R. J. Inorg. Chem. 24 (1985) 1006.

9. Moreland, J. A. and Doedens, R. J. J. Am. Chem. Soc. 97 (1975) 508.

10. Hamilton, W. C. Acta Crystallogr. 18 (1965) 502.

11. Cromer, D. T. and Liberman, D. J. Chem. Phys. 53 (1970) 1891.

12. Cromer, D. T. and Mann, J. B. Acta Crystallogr. Sect. A 24 (1968) 321.

13. Stewart, R. F., Davidson, E. R. and Simpson, W. T. J. Chem. Phys. 42 (1965) 3175.

14. Kato, M., Jonassen, H. B. and Fanning, J. C. Chem. Rev. 64 (1964) 99.

15. Melnik, M. Coord. Chem. Rev. 42 (1982) 259.

16. Porter, L. C. and Doedens, R. J. Inorg. Chem. 23 (1984) 997.

17. Melnik, M. Coord. Chem. Rev. 36 (1981) 1.

18. Marzilli, L. G., Epps, L. A., Sorrell, T. and Kistenmacher, T. J. J. Am. Chem. Soc. 97 (1975) 3351.

19. Krentzien, H. J., Clarke, M. J. and Taube, H. Bioinorg. Chem. 4 (1975) 143.

20. Hodgson, P. J. Prog. Inorg. Chem. 23 (1977) 211.

21. Sutor, D. J. Acta Crystallogr. 11 (1958) 453.

22. Shefter, E. J. Pharm. Sci. 57 (1968) 1163.

23. Mercer, A. and Trotter, J. Acta Crystallogr. Sect. B34 (1978) 450 .

24. Kistenmacher, T. J. and Sorrell, T. Acta Crystallogr. Sect. B 31 (1975) 489.

25. Thiessen, W. E., Levy, H. A. and Flaig, B. D. Acta Crystallogr. Sect. B 34 (1978) 2495.

26. Nakao, S., Fujii, S., Sakaki, T. and Tomita, K.-I. Acta Crystallogr. Sect. B33 (1977) 1373.

27. Steward, O. W., Kato, M., Chang, S. C., Sax, M., Chang, C. H., Taura, T., Jury, C. F., Muto, Y., Tokii, T., Pletcher, J. and Yoo, C. S. Proc. 23rd Int. Conf. Coord. Chem., Boulder, CO, USA, July 29 August 3, 1984, p. 247.

28. Kato, M., Taura, T., Steward, O. W., Tokii, T., Muto, Y., Kushi, Y. and Suzuki, I. Proc. 33rd Conf. Coord. Chem. Chem. Soc. Jpn., Toyonaka, Japan, October 1983, p. 494. 


\section{CU(II) TRICHLOROACETATE DIMER}

29. Price, J.H., Pilbrow, J.R., Murray, K. S. and Smith, T. D. J. Chem. Soc. A (1970) 968.

30. Horie, H., Nakashima, M., Tokii, T., Muto, Y., Kato, M. and Suzuki, I. Proc. 33rd Conf. Coord. Chem. Chem. Soc. Jpn. Nagaoka, Japan, October 1983, p. 476.

31. Wasson, J. R., Shyr, C.-I. and Trapp, C. Inorg. Chem. 7 (1968) 469.
32. Muto, Y. et al. Unpublished data; Erre, L. S., Micera, G., Piu, P., Cariati, F. and Ciani, G. Inorg. Chem. 24 (1985) 2297.

Received May 26, 1986. 